\title{
TRABALHADORAS DOMÉSTICAS: MEMÓRIAS, RESISTÊNCIAS E CRIAÇÃO DE DIREITOS (SÃO PAULO, AMAZÔNIA E TANTOS LUGARES, DE UM TEMPO RECENTE E DE AINDA AGORA)*
}

\author{
DOMESTIC WORKERS: MEMORIES, RESISTANCES AND RIGHTS \\ CREATION (SÃO PAULO, AMAZON AND MANY PLACES, OF A \\ RECENT TIME AND EVEN NOW)
}

\author{
Vanessa Miranda ${ }^{1}$ \\ Maria do Rosário da Cunha Peixoto ${ }^{2}$ \\ Nelson Tomelin $\mathrm{Jr}^{3}$
}

\begin{abstract}
RESUMO: A partir de pesquisa de materiais de comunicação popular e outras fontes (narrativas orais e processos judiciais), o presente artigo busca problematizar memórias e resistências de trabalhadoras domésticas politicamente organizadas, ou não organizadas, em São Paulo, na Amazônia, e em outros lugares, durante período que atravessa a ditadura civil-militar no Brasil (1964/1985). Entendendo o processo de produção da memória como um meio de disputas entre o hegemônico e o dissidente, buscamos evidenciar que a elaboração desses materiais se constituiu em força ativa de mobilização de um amplo campo de lutas políticas, momento em que também aquelas trabalhadoras se afirmaram como sujeitos históricos por processos de participação social, criação e conquista de direitos na cidade.
\end{abstract}

PALAVRAS-CHAVE: Trabalhadoras domésticas, ditadura civil-militar, resistências, direitos, memórias.

\footnotetext{
* Temas aqui desenvolvidos foram originalmente apresentados em tese de doutoramento defendida na PUC-SP, com auxílio de bolsa de estudos do CNPq, conf. MIRANDA (2020). Outros resultados deste artigo contaram com o incentivo da FAPEAM (Edital n. 006/2019 Universal Amazonas). O apoio interinstitucional no âmbito dos projetos PROCAD/CAPES Trabalho, Cultura e Cidade (PUC-SP/UFAM/UFCG) e de Professor Visitante (USP/AUCANI) contribuiu para a consolidação de perspectivas comuns de pesquisa.

${ }^{1}$ Psicóloga da Secretaria de Saúde do Estado do Amazonas (SES/Amazonas) e doutora em Psicologia Social pela Pontifícia Universidade Católica de São Paulo (PUC-SP). Orcid: https://orcid.org/0000-0001-7570-3155.

${ }^{2}$ Doutora em História Social pela Universidade de São Paulo. Professora do Departamento de História e do Programa de Estudos Pós-Graduados em História da Pontifícia Universidade Católica de São Paulo (PUC-SP). Orcid: https://orcid.org/0000-0003-4113-8922.

${ }^{3}$ Professor do Departamento de História da Universidade Federal do Amazonas (UFAM). É professor visitante bolsista da Agência USP de Cooperação Acadêmica Nacional e Internacional (AUCANI), vinculado ao Departamento de História e ao Programa de PósGraduação em História Social da Faculdade de Filosofia, Letras e Ciências Humanas da Universidade de São Paulo (FFLCH/USP). Orcid: https://orcid.org/0000-0002-2764-5840.
} 
ABSTRACT: Based on research of popular communication materials and other sources (oral narratives and lawsuits), this article seeks to problematize the memories and resistance of politically organized, or not organized, domestic workers in São Paulo, in the Amazon, and elsewhere, during a period that is going through the civilmilitary dictatorship in Brazil (1964/1985). Understanding the memory production process as a means of disputes between the hegemonic and the dissident, we seek to show that the elaboration of these materials constituted an active force for mobilizing a wide field of political struggles, a moment in which those workers also affirmed themselves as historical subjects through processes of social participation, creation and conquest of rights in the city.

KEYWORDS: Domestic workers, civil-military dictatorship, resistances, rights, memories.

O tema das experiências, resistências e memórias das trabalhadoras domésticas, politicamente organizadas, ou não organizadas, tem merecido a atenção de importantes pesquisadores brasileiros da historiografia, antropologia, sociologia e psicologia, os quais enfatizam sua presença em fontes da imprensa, processos judiciais, narrativas orais, literatura, iconografia, desde a abolição da escravatura (CHALHOUB, 1996; FREYRE, 1957; KOFES, 2001; MATOS, 1994), mas também antes desse período (FREYRE, 1933), e mais recentemente (BOSI, 1999; LEVINE e MEIHY, 1994; SILVA, 2006).

No período pesquisado neste artigo, que atravessa a ditadura civilmilitar (1964/1985), alcançando o seu após, identificamos, tanto pelo levantamento de materiais de comunicação popular quanto pelo trabalho de pesquisa de processos judiciais e fontes orais, que movimentos de trabalhadoras domésticas de São Paulo, da Amazônia brasileira e de tantos lugares conquistaram visibilidade em diferentes espaços nas cidades, associando suas lutas a movimentos de leigos católicos e de reinvindicação por direitos trabalhistas (MIRANDA, 2020).

Déa Ribeiro Fenelon e Yara Aun Khoury destacam em pesquisa sobre a atuação social e política dos movimentos ligados à Igreja Católica entre 1920 e 1980 a presença da categoria doméstica. Nessa oportunidade, mencionaram as historiadoras relevantes boletins de classe e demais documentos, periódicos, fontes de arquivos especializados na guarda, organização e referenciação de 
materiais produzidos pelos movimentos sociais dos cristãos da cidade de São Paulo.
Dentre estes boletins, o que mais nos chamou a atenção foi "Unidas" dirigido à JOCF da Região Sul e que tem números especiais dirigidos às domésticas: chama-se "Unidas Domésticas". Esse boletim faz uma convocação para um Congresso de domésticas no Rio de Janeiro que acabou por não se realizar (FENELON e KHOURY, 1987: 131).

Ney de Souza observa que os boletins "Unidas" e "Unidas Domésticas", ambos editados pela JOC (Juventude Operária Católica), alcançam no período das décadas de 1940 a 1960 tiragem mensal conjunta de "24 mil exemplares" (SOZA, 2018: 62).

Frentes de pesquisa como a enfrentada pelas autoras acima iniciam na década de 1980 com a formação dos chamados Centros de Documentação Popular de diferentes regiões do Brasil (CRUZ, 2013; CPV, Série Documental, 1985; Caderno de Capacitação 8, 1985), encontrando possibilidades de problematização direcionadas à ampla temática de preservação da memória e de seus desdobramentos enquanto instrumento de luta de sujeitos históricos pela garantia dos direitos sociais, do acesso à cidade, à cultura, ao trabalho, à democracia. Analisamos neste artigo o trabalho do CPV (Centro Pastoral Vergueiro/Centro de Documentação e Pesquisa Vergueiro), instituição envolvida na produção da memória de resistência pastoral da classe trabalhadora entre as décadas de 1970 e 1990, e mantenedora do acervo em que a presente pesquisa se fundamenta pelo levantamento de parte das fontes estudadas. O CPV coletou sistematicamente as diversas formas de registro de muitos desses movimentos, oferecendo-lhes, inclusive, assessoria de documentação e comunicação popular para elaboração de materiais impressos e outras práticas de organização social e política.

Em Série Documental de 1985, informa o CPV a aposta dos trabalhos empreendidos por Centros de Documentação em uma ação que

coloca diretamente a utilização da documentação como um dos instrumentos cotidianos que os setores populares têm a seu alcance para dinamizar suas lutas. Isso implica duas instâncias: procurar a melhor maneira de apoiar setores populares para os mesmos progredirem na tarefa de 
documentar sua própria prática a fim de possibilitar uma acumulação de experiências que permita sua utilização posterior, e com a finalidade de comunicar sua aprendizagem social e política a outros grupos populares. (CPV, Série Documental, 1985).

Identificamos nessa trajetória de construção do CPV, oportunidades no campo da pesquisa sobre a participação da categoria das trabalhadoras domésticas na produção social da memória e de espaços de resistência nas cidades. Procuramos relacionar dimensões de práticas sociais de invenção de democracia em processos de formação histórica da cidade pela experiência de sujeitos históricos muitas vezes invisibilizados em seus modos de viver e criar cidadania cultural (MUNAKATA, 2010 e PAOLI; SADER; TELLES, 1983). Acompanhamos Claude Lefort ao observar esse autor que a sociedade é indeterminada, inapreensível, indomesticável (1983: 118). Dito de outra forma, as relações que definem os diferentes tempos históricos que engendram o social constituem-se simultaneamente como fazeres, expressões pensadas, perspectivas e presentes inúmeros.

Pela afirmação de múltiplos lugares do social e dimensões do político, invenções de experiências e culturas, neste artigo, busca-se superar a ideologia de uma sociedade homogênea e transparente a si mesma, reservada por direito à ação de engenheiros, planejadores, e seus sobrevoos de poder e saber. No oposto desse caminho, buscamos compreender experiências diversas dos movimentos sociais das trabalhadoras domésticas e perspectivas de suas construções institucionais entre 1964 e 1985, em São Paulo e na Amazônia brasileira, evidenciando tais conflitos e diversidade de posições como dimensões constitutivas do processo histórico, e da invenção democrática ${ }^{4}$ no país.

Registra Yara Aun Khoury (1991), em inventário sobre o Fundo Juventude Operária Católica (JOCB) do Centro de Documentação e Informação

\footnotetext{
${ }^{4}$ Com a expressão "invenção democrática", Claude Lefort (1983) enfatiza a pluralidade de lugares de produção do social como característica central da democracia, dimensão atacada por perspectivas totalitárias que buscam a centralidade burocrática do Estado e sua identificação integral com a sociedade civil.
} 
Científica "Prof. Casemiro dos Reis Filho" (CEDIC/PUC-SP), que em 1961 ocorre o I Congresso de Jovens Empregadas Domésticas no Rio de Janeiro, do que resulta a criação de Associação da categoria naquele estado. $\mathrm{O}$ importante jornal carioca Correio da Manhã noticia o evento, mencionando a participação de vinte e cinco jovens "chegadas de vários Estados". Reproduzimos trecho da reportagem, a fim de evidenciar o tratamento da temática e articulação desta no campo mais amplo das notícias trazidas então por esse periódico - um dos "mais importantes impressos do Rio no período" (CHAMMAS, 2011) e, que, posteriormente, apoiaria o Golpe de 1964.

PESSOA DA FAMÍLIA

- A doméstica é, sem dúvida, uma pessoa da família. De um modo geral afeiçoa-se aos patrões e aos filhos destes. Fica às vezes prêza a um emprêgo pela dedicação aos que lhe são caros - disse a responsável pelo serviço de Domésticas da JOC Nacional.

Concluindo:

- Por que não se retribuir êsse carinho, então, essa amizade, êsse amor saído espontâneamente dos corações das jovens empregadas domésticas? São membros das famílias ligados por estritos laços de afeto e amor. Sejamos mais amigos de nossas empregadas e tratemo-las com o carinho que bem merecem essas indispensáveis criaturas, filhas de Deus como nós! (CORREIO DA MANHÃ, 11/01/1961)

As declarações atribuídas pelo jornal à representante da JOC no evento, Denise Verschueren - missionária belga ligada à JOC daquele período (BERNARDINO-COSTA, 2007: 151), surpreende pelo tom condescendente e violência classista, sublinhando supostas "qualidades" valorizadas na profissão. Sem desatentar para a possibilidade de ambiguidades e contradições na trajetória dos movimentos sociais e suas lideranças, o conteúdo da matéria parece antes alinhado com as articulações do jornal na sociedade daquele momento do que com a militância da classe trabalhadora organizada. Diferenças quanto ao modo como as lutas e resistências dessas mulheres eram veiculadas pela grande imprensa podem ser observadas na comparação com materiais de comunicação popular divulgados anos depois por trabalhadoras domésticas na organização de novo encontro da categoria. 
Abaixo, cartaz do VI Congresso Nacional de Empregadas Domésticas realizado na cidade de Nova Venesa, no Estado de São Paulo, entre os dias 19 e 22 de janeiro de 1989, explora conjunto de elementos visuais que apontam para um diálogo de luta por direitos entre setores da sociedade em perspectiva de comunicação popular por auto-organização. São mulheres altivas, negras, brancas, e de traços afro-indígenas, eventualmente jovens, trabalhadorasestudantes, em autorrepresentação que nega a percepção desse grupo social comumente veiculada pela grande imprensa.

Figura 1 - Cartaz do VI Congresso Nacional de Empregadas Domésticas, Nova Venesa/SP, 1989.

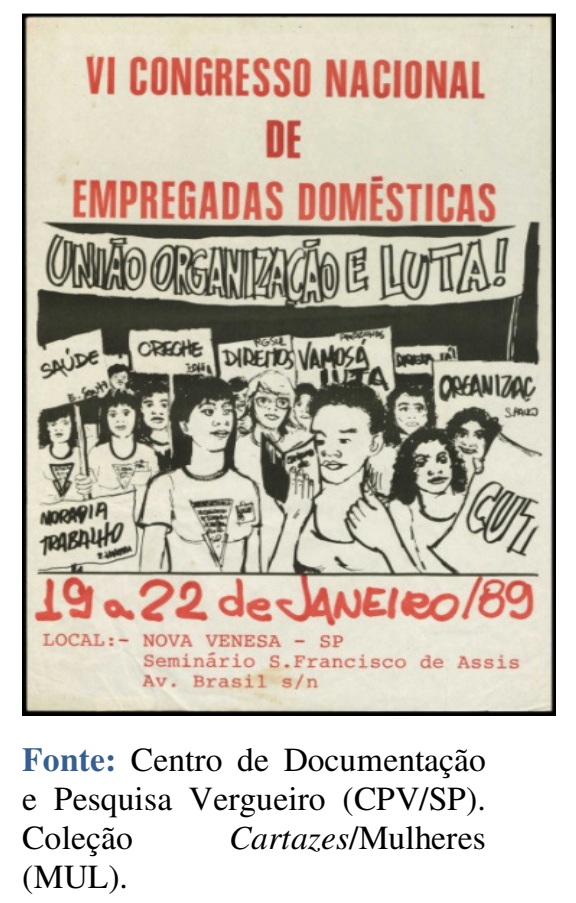

Evidencia ainda o cartaz a aposta na organização mais ampla do movimento, com a inscrição das iniciais da CUT (Central Única dos Trabalhadores) em cartolina no canto direito inferior do quadro, estando também aí representadas frentes de lutas por direitos reivindicados por movimentos específicos daquele momento, de "moradia", "creche", "saúde", "trabalho", e, sobretudo, pelo direito à "união", como expõe a faixa central 
superior do cartaz. Trata-se da invenção da democracia, trabalho que envolve diálogo entre diferentes saberes e fazeres da prática popular.

Marilena Chaui, em diálogo com a obra de Claude Lefort, observa a criação de direitos como "invenção contínua do social e do político através das divisões e dos conflitos". (CHAUI, 1983: 12). Em trajetória de estudos voltados prioritariamente para a revalorização da cultura e da democracia como criação de direitos, a filósofa afasta com lucidez dimensões de iniciativas vanguardistas ou autodefinidas extemporâneas, preferindo, em vez disso, a análise de processo e constituição de modos de vida, de luta e de trabalho pela classe trabalhadora, relacionando sempre, na melhor tradição do pensamento gramsciano, ${ }^{5}$ a formação de hegemonias a fazeres contra-hegemônicos, a aposta no futuro e na utopia, no movimento (FENELON, 1992 e 1995; THOMPSON, 1981; WILLIAMS, 1979 e 2015). Para Chaui (1983: 11), “a democracia é invenção porque, longe de ser a mera conservação de direitos, é a criação ininterrupta de novos direitos, a subversão contínua do estabelecido, a reinstituição permanente do social e do político". Daí a indissociação entre história e política: "como criação de direitos, como reconhecimento das divisões internas e das diferenças constitutivas do social e do político, a democracia abre para a história no sentido forte da palavra" (CHAUI, 1983: 11). Também por esse prisma Edward W. Said (2011: 485) se questiona sobre a eventual falta de compreensão de seus companheiros de profissão (cientistas sociais) quanto à interdependência orgânica entre a aposta de suas possibilidades de reflexão e pesquisa e as práticas de defesa e invenção da democracia.

À luz dessas reflexões, queremos contribuir para o debate acerca da atuação das trabalhadoras domésticas na produção de memória de lutas e participação social no período que atravessa a ditadura civil-militar no Brasil

\footnotetext{
${ }^{5}$ Conferir também da autora as obras Conformismo e Resistência: aspectos da cultura popular no Brasil (CHAUI, 1986) e Cultura e democracia: o discurso competente e outras falas (CHAUI, 2003). Marilena Chaui dialoga nesses textos com importantes releituras do marxismo, e compreensões ampliadas sobre o tema da cultura nesse campo, feitas pela historiografia social inglesa e a chamada Escola de Birmingham a partir do conceito de hegemonia de Antonio Gramsci. Sobre a importância do autor italiano nos estudos culturais da escola inglesa, conf. CEVASCO (2008).
} 
(1964/1985), com a criação, conquista e manutenção de políticas públicas que alcançam direitos em demandas diversas, por moradia, segurança alimentar, salário, cidadania cultural, saúde. ${ }^{6}$ A conquista com a promulgação e regulamentação recente da Emenda Constitucional n. 72, de 02 de abril de 2013 (a PEC das domésticas/Regulamentada pela Lei Complementar n. 150, de $1^{\circ}$ de junho de 2015) ${ }^{7}$ pelo governo federal, na presidência de Dilma Roussef, remonta àquelas lutas. $\mathrm{O}$ amadurecimento de temáticas de direitos humanos $\mathrm{e}$ trabalhistas que inúmeras militantes daquele período, em diálogo com diversos setores e instituições da sociedade, ajudaram a construir coletivamente como políticas nacionais (BRASIL/Plano Nacional de Políticas para as Mulheres, 2004), desde o Governo Lula, representou um salto expressivo no acesso

${ }^{6} \mathrm{O}$ presente texto foi finalizado em meio à pandemia de COVID-19, quadro que evidencia, com o saldo de milhares de mortos no Brasil, e no mundo, o resultado de décadas de exploração por políticas neoliberais na área da saúde, com o recurso, em muitos países como o nosso, de golpes de estado e da instalação de ditaduras para esse fim. A atual crise sanitária, que ataca frontalmente a classe trabalhadora, tem sido especialmente ameaçadora para as trabalhadoras domésticas, suas primeiras vítimas no país. Conf. de Melo (2020) a reportagem para o Portal UOL, Primeira vítima do RJ era doméstica e pegou coronavírus da patroa no Leblon.

${ }^{7}$ Os marcos legislativos referentes a essa categoria profissional remontam ao Código Civil de 1916 (Lei n. 3.071, de 01 de janeiro de 1916), com a menção de "criados e mais pessoas do serviço doméstico", arrolados então como os últimos beneficiários da execução de bens para o pagamento de dívida de salário em caso de falecimento de "patrões" e "amos". Com o decreto n. 16.107, de 30 de julho de 1923, aprova-se o regulamento da locação de serviços domésticos, compreendendo a categoria "os cozinheiros e ajudantes, copeiros, arrumadores, lavadeiras, engommadeiras, jardineiros, hortelões, porteiros ou serventes, enceradores, amas seccas ou de loite, costureiras, damas de companhia e, de um modo geral, todos quantos se empregam, à soldada, em quaesquer outros serviços de natureza identica, em hoteis, restaurantes ou casas de pasto, pensões, bars, escriptorios ou consultorios e casas particulares". Em 1941, com o decreto lei n. 3.078, de 27 de fevereiro de 1941, restringe-se a tipificação de "empregados domésticos" àqueles que "prestem serviços em residências particulares ou a benefício destas". Com a CLT (Decreto Lei n. 5.452, de $1^{\circ}$ de maio de 1943), a categoria é definida como prestadora de "serviços de natureza não-econômica à pessoa ou à família, no âmbito residencial destas", desacolhida, assim, da aplicação daquelas Leis do Trabalho. O conhecimento de direitos previdenciários vem pela lei n. 3.807, de 26 de agosto de 1960; a inclusão no quadro de segurados de acidente de trabalho pela lei orgânica da previdência social é definida em 1967, com a lei n. 5.316 de 14 de setembro. Em 1972, com a lei n. 5.859, de 11 de dezembro, o governo de Emílio Garrastazu Médici parece reconhecer o mínimo para não ceder as pressões das trabalhadoras pelo justo: define-se o "direito a férias anuais remuneradas de 20 (vinte) dias úteis, após cada período de 12 (doze) meses de trabalho, prestado à mesma pessoa ou família". Efetivamente, a categoria será reconhecida em seu direito fundamental de associação sindical e luta apenas com a Constituição Federal de 1988, tendo também consolidadas garantias mínimas de trabalhadoras e trabalhadores assalariados, alcançando assim novo patamar de organização e resistência. Contudo, a igualdade de direitos sociais reconhecida já na carta magna para os demais trabalhadores, a categoria alcançará somente em 2013, regulamentadas essas conquistas pela lei complementar n. 150 , de $1^{\circ}$ de junho de 2015 . Tal quadro de avanços legislativos, desde 1916 até o tempo presente, é evidência da organização e luta contínua da classe trabalhadora doméstica no Brasil, com predominante e expressiva presença de mulheres nesse meio. 
daquelas trabalhadoras à cidadania social e cultural. Com a nova redação dada ao parágrafo único do art. $7^{\circ}$ da Constituição Federal, estabelecida a igualdade de direitos trabalhistas entre os trabalhadores domésticos e os demais trabalhadores urbanos e rurais, reposicionam-se perspectivas de resistência e relação social de toda a sociedade brasileira. O impacto político de tal mudança (e outras, como o Programa Bolsa Família, Fome Zero, Minha Casa Minha Visa, REUNI/MEC, PRONAF, Lei Maria da Penha) foi tamanho que não são poucas as análises do tempo recente que relacionam a condição de tais conquistas da classe trabalhadora com os protestos midiatizados de junho de 2013 e o desfecho do golpe de estado de 2016, por ilegítimo processo parlamentar de cassação do mandato da então presidenta Dilma, momento em que setores do empresariado e seus representantes congressuais, o judiciário, a grande imprensa e parcela da classe média se articularam pela retirada de direitos e retrocessos no campo da justiça econômica e da igualdade social, com prejuízos expressivos para as trabalhadoras domésticas (POCHMANN, 2017).

O que buscamos tratar neste artigo é precisamente do processo histórico de invenção de um "momento em que o político não fosse concebido como um lugar fixado pelas estruturas sociais e determinações econômicas" (PAOLI et al, 1983: 131), o que emerge de memórias e táticas implícitas e explícitas da luta de mulheres trabalhadoras domésticas na definição dos rumos sociais de seu próprio futuro, como disputa e criação de novos valores e direitos, e defesa de seus modos culturais próprios de viver, trabalhar e resistir. A sociedade em desenvolvimento, suas instituições em aperfeiçoamento, dirá Raymond Williams, se constroem e reconstroem "sob a pressão da experiência", "pela descoberta de direções e significados comuns", "em cada modo de pensar individual", o que empresta ao conceito de cultura dimensão "tanto tradicional quanto criativa" (WILLIAMS, 2015: 5). Pensar assim os movimentos do trabalho, da observação, e da comunicação popular, entendendo a construção contraditória do fazer-se e refazer-se de tais dimensões da vida em comum, em debate social ativo, pode evidenciar diferenças na unidade, perspectivas que demonstram que a história, como nos ensina Walter Benjamin, não é a 
"marcha" de "um tempo vazio e homogêneo", cumprido por etapas, estrategicamente planejadas, rumo ao "progresso". Por isso, lembra o filósofo alemão, "a crítica dessa ideia do progresso tem como pressuposto a crítica da ideia dessa marcha" (BENJAMIN,1994: 229).

\section{Trabalhadoras domésticas e comunicação popular}

As fontes levantadas para a presente pesquisa acompanham expressões de comunicação popular na imprensa nanica como "força social ativa" (CRUZ e PEIXOTO, 2007), boletins de classe e de bairro, a militância pelo direito à memória do Centro Pastoral Vergueiro (CPV). Destacamos também narrativas (orais e judiciais) que ao longo do período evidenciaram a presença de sujeitos diversos, católicos, operários, escritores, estudantes e professores, cartunistas, movimentos urbanos, que ao lado das trabalhadoras domésticas demarcaram então territórios históricos amplos de mobilização.

O Centro Pastoral Vergueiro (CPV), atualmente Centro de Documentação e Pesquisa Vergueiro, foi fundado em 1973, por frades dominicanos que passam a reunir na região sudeste de São Paulo, nos fundos da Capela Cristo Operário, militantes de movimentos sociais de esquerda, professores e estudantes universitários, com “o compromisso de preservar a memória de resistência e organização popular, mas não para armazená-la apenas, mas para divulgá-la para que servisse de instrumento de transformação" (SITE CPV, s/n). ${ }^{8}$ Com o fim daquela ação pastoral e social, o CPV assume a função de Centro de Documentação e Pesquisa (com mais de 200 mil documentos preservados - textuais, bibliográficos, iconográficos e sonoros), apoiando investigações científicas no campo da história, psicologia, sociologia, e outras áreas das ciências sociais. Pelo sistemático trabalho de coleta, organização e preservação que se estende desde a sua fundação, o CPV mantém viva a memória de sujeitos e práticas sociais da classe trabalhadora da grande São Paulo e de outras regiões do Brasil. Vale ressaltar que os dominicanos

\footnotetext{
${ }^{8}$ Sobre o tema, conf. também SALLES (2013).
} 
envolvidos naquele projeto inicial (frei Giorgio Callegari, frei José de Rezende Ribeiro, frei Queiróz, frei Romeu Dale) participaram da luta armada no final da década de 1960, durante a ditatura civil-militar em São Paulo, ocasião em que atuavam na Paróquia do bairro Jardim da Saúde.

De 1973 até 1989, o CPV funcionou nas dependências da Comunidade Cristo Operário, reconhecida, no ano de 2008 como patrimônio histórico e artístico da cidade, não apenas por seu valor arquitetônico (jardins de Burle Marx e pinturas de Alfredo Volpi no interior da capela) e trabalho pastoral, mas também por ter abrigado de 1954 a 1967 a experiência da Unilabor, fábrica de móveis ligada ao Círculo Operário e parte do sindicalismo da época. Trata-se de diferentes experiências e temporalidades dentro do próprio movimento operário. Ao longo de sua existência, o CPV conservou característica da qual nunca se distanciou, como enfrentamento no campo do direito à memória (SÃO PAULO; SMC; DPH, 1992): a preocupação de documentar os registros da classe operária, de criar materiais próprios de divulgação, e de oferecer suporte aos movimentos populares em suas trajetórias de luta. Tal trabalho, desenvolvido ao longo de décadas, desdobra-se em práticas de comunicação $e$ documentação popular, com metodologia inovadora de trabalho, organização e patrimonialização documental que acompanhou pari passu as lutas dos trabalhadores de diferentes segmentos.

Ainda sobre perspectivas de articulação ampla das mobilizações populares entre setores e categorias profissionais diversas da classe trabalhadora, conforme salientamos mais acima na introdução do texto, gostaríamos de ressaltar também outras formas pelas quais esses sujeitos históricos aparecem representados na imprensa de comunicação popular do período, precisamente pela valorização do que pensam e entendem do movimento a partir de sua experiência própria, superando olhares de desvalorização da classe dominante. ${ }^{9}$

\footnotetext{
${ }^{9}$ Eder Sader, no livro Quando novos personagens entraram em cena, expõe esse quadro de violências pela percepção própria da classe trabalhadora organizada. O autor registra a fala de militante de "clube de mães" da Vila Remo, no ABC paulista, que lembra com indignação das visitas de mulheres do "Lions Club" que antes ali realizavam reuniões para "fazer o bem,
} 
A partir de órgão informativo vinculado à Comissão de Direitos Humanos da cidade de Lins, o Jornal $A$ voz do povo, destacamos a presença de domésticas em movimentos organizados do interior do Estado de São Paulo, bem como a opção e escolha daquele informativo em sublinhar a participação dessas mulheres nas lutas aí noticiadas. Na edição n. 4, de 1980, informa o jornal sobre a realização do $1^{\circ}$ Encontro dos Trabalhadores de Lins, no $1^{\circ}$ de maio daquele ano, com a presença de "quase 80 trabalhadores de várias categorias".

Era a primeira vez que em nossa cidade um número tão grande de operários, bóias-frias, empregadasdomésticas, pedreiros, comerciários se reunia para conversar sobre o seu trabalho. Teve lanche para todo mundo e até moda de viola. Uma coisa ficou clara: os trabalhadores precisam se reunir mais, falar de seus problemas, lutar juntos...

E na sequência, as percepções próprias do encontro por "Dona Lurdes, empregada doméstica”. O texto está citado entre aspas no Jornal:

"Teve também um teatro, com as próprias empregadas domésticas. Teve lanche, cinema para as crianças. Depois todos foram divididos em grupos de cada categoria. $\mathrm{O}$ grupo das empregadas domésticas discutiu e chegou a um acordo, de se juntarem todas e de lutarem por esses objetivos: salários e uma creche no Parque S. Jorge. No nosso encontro também uma lavadeira leu uma carta e dizia que as lavadeiras lavam muita roupa, tomam friagem, ficam com reumatismo e elas não tem condição de pagar o INPS e que gastam energia, água, sabão e o que ganham não dá para pagar tudo isso. As patroas não querem aumentar o ordenado" (Jornal $A$ voz do povo, n. 4, ano 1980 / Coleção Periódicos / Arquivo CPV).

Abaixo, reproduzimos fotografia da página do jornal que acompanha o relato de Dona Lurdes. A imagem recebeu legenda em que se observa que “durante o teatro, feito pelas empregadas, todo mundo prestou muita atenção. Elas mostraram como são injustiçadas e que só se unindo podem acabar com essa situação".

alguma coisa pelos outros". Menciona a trabalhadora que, nessas atividades, entre outras agressões, as senhoras ricas da cidade davam dicas de higiene: "que se nós não tivéssemos pasta de dente para escovar os dentes, escovasse com bicarbonato, se nós não pudéssemos ter desodorante, que usasse limão, que também saía o cheiro" (SADER, 1988: 201). 
Figura 2 - Trabalhadoras domésticas em apresentação de teatro/ $1^{\circ}$ Encontro dos Trabalhadores de Lins, $1^{\circ}$ de maio de 1980/Foto publicada no Jornal $A \mathrm{voz}$ do povo, n. 4, ano 1980: 03.

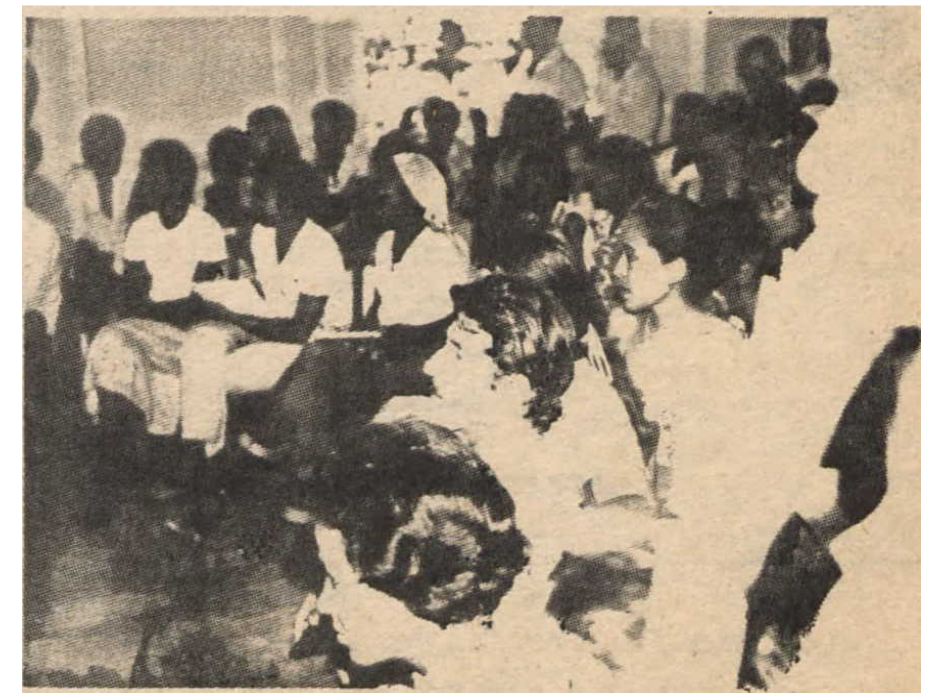

Fonte: Centro de Documentação e Pesquisa Vergueiro (CPV/SP)/Coleção Periódicos.

O direito à cidadania cultural - poder fazer teatro, mais do que assistir o espetáculo (CHAUI; CANDIDO; ABRAMO; MOSTAÇO, 1985) - alcança nessa fotografia o sentido forte de que não apenas realizam as trabalhadoras domésticas o exercício da dramaturgia e da direção, como o prazer de fazer especialmente para os seus companheiros, de movimento e profissão. Também nessa edição do periódico, são fortalecidos sentidos políticos de que a amizade se cultiva. Os filhos dos trabalhadores, como observa Lurdes, também participam. Na legenda da imagem abaixo se lê que "as crianças se divertiram bastante. Entre um filme e outro brincavam juntas. Estão aprendendo a se unir desde pequenas" evidenciando que o exercício democrático não tem limite de idade, podendo ser exercido em diferentes espaços de convívio social. 
Figura 3 - Crianças brincando no $1^{\circ}$ Encontro dos Trabalhadores de Lins, $1^{\circ}$ de maio de 1980/Foto publicada no Jornal A voz do povo, n. 4, ano 1980: 04.

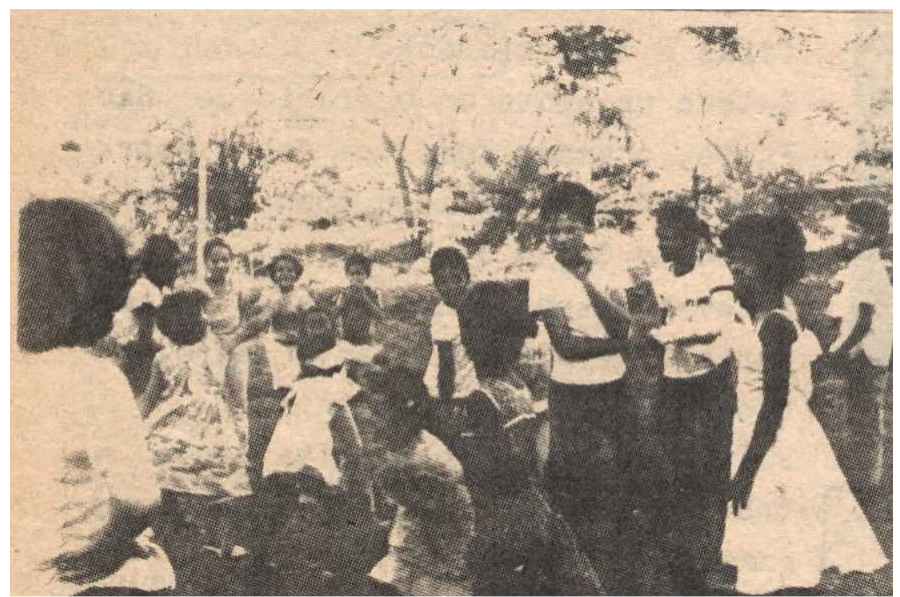

Fonte: Centro de Documentação e Pesquisa Vergueiro (CPV/SP)/Coleção Periódicos.

Importante assinalar nessa imprensa perspectivas de lutas no campo da memória, em que personagens como "Zumbi" e "Santo Dias" são lembrados pela Pastoral dos Negros de Lins e pela Pastoral Operária como mártires da luta dos trabalhadores. As diretrizes de comunicação popular que muitos desses jornais assumiram na época se desenvolveram também como contradiscurso à educação dominante, racista, e excludente dos trabalhadores e trabalhadoras, crianças e velhos pobres do estado de São Paulo.

Heloisa de Faria Cruz (2013), a partir do levantamento de fontes junto ao acervo do CPV, e em outros arquivos, ${ }^{10}$ problematiza processos de articulação e constituição de redes de comunicação dos movimentos sindicais e populares de São Paulo das décadas de 1970 a 1990, com foco de investigação para a produção de materiais impressos alternativos, tanto aqueles de tiragem mais estruturada e regular quanto os de trajetória efêmera e elaboração artesanal. Enfatiza a autora sobre aquela imprensa, que as "formas de autoorganização e das disputas por hegemonia naquele contexto diz respeito às suas linguagens e formas de comunicação" (CRUZ, 2013: n. p). Além disso, Cruz

\footnotetext{
${ }^{10}$ Trabalho realizado no âmbito do Projeto Bicentenário da Imprensa no Brasil: Dimensões da Imprensa Popular em São Paulo, tendo constituído referências sobre mais de 100 publicações e impressos produzidos por movimentos populares e sindicais entre 1970 e 1990, envolvendo equipe de professores da PUC-SP, Heloisa de Faria Cruz, Maria do Rosário da Cunha Peixoto, Yara Aun Khoury, e o apoio de pesquisadores de Iniciação Científica do Conselho Nacional de Desenvolvimento Científico e Tecnológico (CNPq-PUC/SP).
} 
observa que o CPV e outros Centros Populares de Documentação e Comunicação desse momento "devem ser analisados como formações culturais, espaços constitutivos do fazer-se histórico daqueles movimentos" (CRUZ, 2013: n. p). A rede de comunicação que se formou entre essas diversas entidades e os novos movimentos sociais (sindicatos de oposição e movimentos populares), revelam "linguagens, formações culturais e projetos invisíveis em outros registros" (CRUZ, 2013: n. p), sendo importante ainda indicar, diz a autora, que tais publicações e impressos variados constituem "os rastros da formação e atuação de importantes redes de comunicação que conformaram espaços de emergência e afirmação da cultura dos trabalhadores" (CRUZ, 2013: n. p).

Segue reprodução de página inteira do Jornal A voz do povo, de 1981, em que lemos notícia de encontro de trabalhadoras domésticas realizado na Faculdade de Serviço Social de Lins, envolvendo "20 empregadas de Lins e 4 da diretoria da Associação das Empregadas Domésticas de Bauru”. Destaca-se também a aposta dessas publicações em projeto gráfico próprio, com a evidenciação de traços físicos e instrumentos de trabalho da categoria, a qual se via, assim, representada naquelas páginas.

Figura 4 - Página inteira do Jornal $A$ voz do povo, n. 7 (n. 8, anotado a caneta), ano 1981: 04.

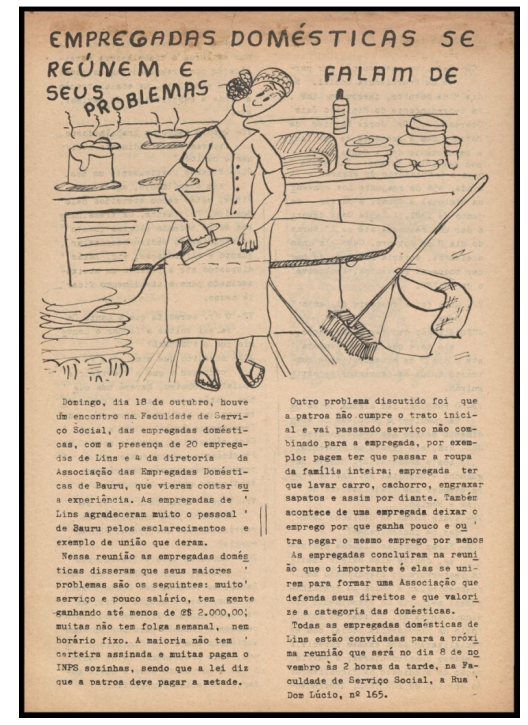

Fonte: Centro de Documentação e Pesquisa Vergueiro (CPV/SP) / Coleção Periódicos. 
Expõe a matéria um quadro de exploração do trabalho das domésticas, com salários baixos, a falta de registro em carteira, além de desvios de função: "ter que passar a roupa da família [expandida] inteira; empregada ter que lavar carro, cachorro, engraxar sapatos, e assim por diante" (Jornal A voz do povo, n.

7. Centro de Documentação e Pesquisa Vergueiro (CPV/SP) / Coleção Periódicos).

Com as proibições, interdições ou dificuldades impostas à organização das trabalhadoras domésticas em sindicatos da categoria, condição jurídica e politicamente vigente no país durante as ditaduras Vargas e civil-militar de 1964, tendo sido reconhecido fundamentalmente esse direito apenas pela Constituição Federal de 1988 (incisos XVII e XXI do artigo $5^{\circ}$ ), fazia-se o movimento de união prioritariamente com a formação de "Associações". ${ }^{11} \mathrm{O}$ Jornal A força do pobre, publicação da CCB de Vila Zilda (Congregação Cristã no Brasil do bairro Vila Zilda da cidade de São Paulo), de fevereiro de 1982, divulga carta-convite da trabalhadora Cecília Maria, da Baixada Santista, convocando demais companheiras de profissão e região para um encontro.

Sou Doméstica, e gostaria de me unir a outras, fazendo assim uma "ASSOCIAÇÃO DE EMPREGADAS DOMÉSTICAS", para discutirmos os nossos direitos. Se você tiver algum interesse em participar e ter o seu trabalho reconhecido e compensado, procure informações na "COMUNIDADE CRISTÃ" da Vila Zilda, pois se Deus quiser, logo estaremos juntas reivindicando os nossos direitos e deixando de ser simples escravas de Madames, que o que gostam mesmo é de nosso serviço e de nos deixar de lado quando não servimos mais. Olhe, se nos unirmos, aqui em Guarujá, não haverá tanta patroa nos oprimindo, pois apesar de aqui ser a "Pérola do Atlântico" de beleza, turismo e tudo mais, Guarujá é também ninho de empregados e empregadas cada vez mais oprimidos. Tchau! até o próximo número do nosso jornal: "A força do pobre". Cecília Maria. (Jornal A força do pobre, n. 5, fevereiro de 1982, ano II / Coleção Periódicos / Arquivo CPV).

\footnotetext{
11 Em 1997 é criada a FENATRAD - Federação Nacional das Empregadas Domésticas, abrangendo hoje plataforma de luta de 26 sindicatos e mais uma associação da categoria. De acordo com a FENATRAD, e segundo indicadores estatísticos do IBGE (2006), a categoria soma atualmente um total de 7,2 milhões de trabalhadoras, respondendo por $21,9 \%$ dos domicílios em que as mulheres com emprego são as principais responsáveis financeiras.
} 
A primeira Associação de Empregadas Domésticas do Brasil foi fundada em Santos, no estado de São Paulo, em 1936, tendo sido cassada em 1942 pela ditadura varguista (1937/1945). Foi protagonista dessa iniciativa, Laudelina de Campos Mello, importante militante da categoria até o seu falecimento na cidade de Campinas em 1991, aos 86 anos, tendo participado de todas as principais conquista do movimento, dando visibilidade para a presença de negros e negras nessas lutas. Credita-se também aos seus esforços a promulgação da PEC das Domésticas em 2013. ${ }^{12}$

Sobre a memória de negros e negras no trabalho doméstico no Brasil, ${ }^{13}$ é contribuição fundamental para todo um ramo de trabalhos acadêmicos no campo da pesquisa em Psicologia Social e História a partir de narrativas orais, o livro de Ecléa Bosi (1999), Memória e Sociedade: lembranças de velhos. A entrevista realizada pela autora com Dona Risoleta, filha e neta de escravos, "vendidos como se vende porco" (BOSI, 1999: 380), talvez seja um dos mais belos capítulos das ciências humanas no país. Nascida em 1900, em uma fazenda perto do "Arraial dos Souzas", na região de Campinas, propriedade dos "Penteado de olho azul, porque tem os Ferreira Penteado que são os castanhos" (BOSI, 1999: 363), Risoleta, próxima dos oitenta anos de idade, expõe em cores vivas as resistências articuladas contra as violências sofridas pelos trabalhadores e trabalhadoras domésticas negras no Brasil, apropriando-se do político como posicionamento, mesmo em situações adversas do cotidiano. Risoleta reconhece conquistas importantes do governo Getúlio Vargas - "Se não fosse o Getúlio até hoje creio que não tinham criado a aposentadoria" (BOSI, 1999: 386) - alicerçadas essas suas percepções à luz das expectativas de retrocessos com o movimento golpista de 1932 no estado de São Paulo.

Eu era cabo eleitoral do Getúlio, quanto eleitor eu arranjava! Nunca votei, mas se torcia! Ele criou caderneta de trabalho. Quando batiam à porta em casa de família diziam pra empregada: "Você vai atender à porta, mas se for fiscal do

\footnotetext{
${ }^{12}$ Sobre o tema, conf. CRESPO (2016).

13 Vale destacar o trabalho de pesquisa Eu, Empregada Doméstica. A Senzala moderna é o quartinho da empregada realizado pela historiadora Preta-Rara (2019), com a reunião de relatos recentes de trabalhadoras domésticas compartilhados em páginas do Facebook.
} 
governo diga que não é empregada, que você é uma pessoa da família que sempre viveu com a gente aqui”. Só pra não tirar a caderneta de trabalho pra gente. As empregadas que trabalhavam a vida inteira ficavam na miséria, morriam no asilo, coitadinhas, sem nada!

(...) Quanta injustiça! Às vezes, uma ou outra patroa tinha o coração no peito, deixava um dinheirinho pras empregadas que trabalharam com ela mais de trinta, quarenta anos, como fez nhá Moça Fortes lá de Campinas com as empregadas dela, como a Quetita. A gente ganhava uma bagatela que não dava pra nada, nem pra se vestir. Tinha que comprar as fazendinhas baratas da Pernambucana pra fazer os vestidinhos e as patroas compravam as fazendas caríssimas delas e não davam nunca para a empregada vestir, pra ela não ficar chique. Que espírito atrasado que elas tinham! Viajavam, estudavam, eram cheios de orgulho. Se a gente chegava e eles estavam sentados na sala a gente conversava o tempo inteiro de pé, não podia sentar junto com eles. Isso não é uma afronta? Hoje eles não são mais assim, conversam, sentam na mesa com a gente, comem. (BOSI, 1999: 385).

A narrativa de Risoleta contribui para entendermos dimensões ideológicas e de negação de direitos às trabalhadoras domésticas conforme relatado na reportagem "Pessoa da Família", publicada em matéria do Correio da Manhã citada mais acima. Também faz pensar o trecho em sentidos da exclusão veiculados pela grande mídia no Brasil por ocasião do Golpe de 2016, momento em que as conquistas alcançadas pelos trabalhadores de um modo geral, mas principalmente pelas trabalhadoras domésticas e suas famílias, com a garantia de acesso amplo a direitos como o consumo de melhores vestuários, viagens e ingresso em prestigiadas instituições públicas de ensino superior, no país e no exterior, foram alvo de duros ataques pela classe dominante brasileira.

Acompanhamos aqui perspectivas de análise histórica articuladas com o tempo presente conforme propostas por Beatriz Sarlo ao enfatizar a autora que “os 'fatos históricos' seriam inobserváveis (invisíveis) se não estivessem articulados em algum sistema prévio que fixa seu significado não no passado, mas no presente" (2007: 114). Ecléa Bosi (1994: 59), a partir de leitura original da obra de Maurice Halbwachs, relaciona presente e futuro, fazendo lembrar Alessandro Portelli, quando afirma esse historiador que o testemunho oral pode "recuperar não apenas os aspectos materiais do sucedido como também a 
atitude do narrador em relação a eventos, à subjetividade, à imaginação e ao desejo, que cada indivíduo investe em sua relação com a história" (1993:41).

As memórias de Dona Risoleta evidenciam um campo de disputas tecido na fibra cotidiana e viva de muitos sonhos, ambiguidades, contradições, desejos e projetos políticos alternativos de sociedade (BLOCH, 2001: 60; LE GOFF, 2013: 212; KOSSELECK, 1979: 41), enfim, a aposta que a classe trabalhadora como sujeito da história faz na utopia, no diálogo, na democracia. São contrapoderes que ameaçam "vencedores", e outros "assassinos da memória” (VESENTINI e DE DECCA, 1976; VIDAL-NAQUET, 1988).

Tantos lugares, muitas mulheres, outras resistências

Neste tópico, apresentamos dimensões sociais e culturais das resistências de mulheres trabalhadoras domésticas na Amazônia brasileira em três situações específicas: na justiça trabalhista, no movimento indígena e na imprensa popular.

Apostamos nesta análise no fortalecimento de perspectivas em pesquisas históricas que visam evidenciar experiências de superação de dicotomias e divisões de gênero (PERROT, 2001 e 2005; SAMARA et al., 1997). Desse modo, seguimos encaminhamentos teórico-metodológicos consolidados na área. Joan Scott (1990) lembra de Natalie Zemon Davis quando essa autora observa que deveríamos nos interessar pela história tanto dos homens quanto das mulheres, e que não deveríamos trabalhar unicamente sobre o sexo oprimido, do mesmo jeito que um historiador das classes não pode fixar seu olhar unicamente sobre os camponeses. Nosso objetivo é entender a importância dos sexos dos grupos de gênero no passado histórico. Nosso objetivo é descobrir a amplitude dos papéis sexuais e do simbolismo sexual nas várias sociedades e épocas, achar qual o seu sentido e como funcionavam para manter a ordem social e para mudá-la. (SCOTT, 1990: 3). 
É nesse sentido que achamos importante tratar, ainda que rapidamente, ${ }^{14}$ da participação das mulheres na justiça trabalhista. O assunto é candente ao se abordar a experiência de trabalhadoras domésticas no Brasil, ontem e hoje. E também por enfrentarmos no presente retrocessos expressivos no setor, com a volta das perspectivas institucionais trabalhistas de legitimação do negociado sobre o legislado, como víamos na ditadura civil-militar de 1964, de incentivo à terceirização de atividades fins, e ao trabalho escravo (Reforma Trabalhista, Lei n. 13.467, de 13 de julho de 2017; Ministério do Trabalho, pela Portaria $n^{\circ}$. 1.129, de 13 de outubro de 2017), além de ataques diretos ao direito de aposentadoria de parcela imensa da classe trabalhadora pobre do país (Proposta de Emenda à Constituição - PEC 6/2019).

Em 15 de janeiro de 1986, C. reclama contra R. o pagamento de aviso prévio, $13^{\circ}$ salário proporcional, férias proporcionais, salários retidos, anotação de CTPS (Carteira de Trabalho e Previdência Social), FGTS, juros e correção monetária, totalizando a quantia de $\mathrm{C} \$ 2.832 .800$. O processo foi apresentado à Junta de Conciliação e Julgamento de Itacoatiara ${ }^{15}$ pela própria trabalhadora, acompanhada da mãe, e sem a representação de advogado ou sindicato. ${ }^{16}$

Anexo ao processo consta "contrato particular de locação de serviços domésticos" assinado entre as partes (R., o locador, e C., a locatária), com o reconhecimento de seis testemunhas. Quanto às obrigações da trabalhadora estabelecidas naquele documento, define-se também como um dos seus serviços domésticos, entre outras atividades de limpeza e arrumação da residência, a lavagem e "engomagem" de roupas, "zelar e guardar objetos do locador", além

\footnotetext{
${ }^{14}$ Em outra oportunidade, abordamos o problema mais detidamente. Conf. TOMELIN Jr. e PEIXOTO (2017).

${ }^{15}$ Os processos trabalhistas da antiga Junta de Conciliação e Julgamento do Município de Itacoatiara (JCJ-ITA) compõem conjunto documental preservado pelo Centro de Memória da Justiça do Trabalho da $11^{\mathrm{a}}$ Região (CEMEJ/TRT $11^{\mathrm{a}}$ Região) de Manaus. Pelo levantamento do processo em tela, agradecemos ao pesquisador Avelino Pedro Nunes Bentes da Silva, bolsista de iniciação científica vinculado ao Projeto Universal Amazonas/FAPEAM 2015-2018 "Cidade, cultura e saúde: processos trabalhistas, modos de vida, trabalho e resistência de trabalhadores em Itacoatiara (1973/2004)", coordenado por Nelson Tomelin Jr.

${ }^{16}$ As Juntas de Conciliação e Julgamento eram instituídas prioritariamente em áreas com significativa importância econômica, "onde se verificava maior incidência de conflitos trabalhistas" (MONTENEGRO, 2013: 330), cumprindo papel mediador no campo das contradições acirradas nesses lugares.
} 
de "em caso de doênças (sic.), molezas sempre ao lado do mesmo, prestar outros serviços como sejam recorrer aos médicos em casos de doênças ou moléstias, etc.”. O patrão, por sua vez, se obriga "a prestar todas as assistências a locatária C. bem como aos seus filhos dando aos mesmos alimentação necessárias, como assistências médicas e hospitalar, roupas, calçados e mais que a mesma precisar". Ambos contratantes eram naturais da cidade de Itacoatiara, contando a trabalhadora dezesseis anos de idade na altura desse contrato, e o patrão, "casado, padeiro", vinte anos. Previa ainda aquele instrumento de locação de serviços, em item contratual detalhado, a concordância prévia da adolescente em acompanhar o patrão em caso de transferência dele para outra localidade, mantidas nessa hipótese suas obrigações quanto aos referidos serviços domésticos. O documento estabelece o prazo de vigência de cinco anos.

Entre a data da assinatura do contrato acima e a reclamação de direitos pela jovem trabalhadora na Junta de Conciliação e Julgamento de Itacoatiara transcorre breve período de cinco meses. Prejudicada uma primeira audiência com a juíza do trabalho então responsável, em razão da ausência do patrão, não citado judicialmente por suposta dificuldade de localização do endereço de sua residência (ao que se dispôs a trabalhadora a acompanhar o oficial de justiça em uma segunda tentativa), segue-se nova audiência, em 04 de fevereiro de 1986, agora com ambas as partes presentes. A adolescente está acompanhada de sua genitora.

Em contestação alega o reclamado que não era sua empregada mas sim sua "mulher"; que foi a reclamante que não mais quis continuar com o reclamado. Inquirido o reclamado sobre as cláusulas contratuais [contrato supracitado de locação de serviços domésticos] alega que as desconhece. Recusada a primeira proposta conciliatória. A Junta fixa a alçada no valor líquido do pedido. Interrogada a reclamante, declarou: que passou a viver com o reclamado após a assinatura do contrato; que cuidava da casa e do próprio reclamado; que trabalhava numa padaria a ele alugada; que as vezes ia até a padaria, quando ajudava o reclamado; que o contrato foi feito para viver com o reclamado; que deixou o reclamado porque era por ele espancada; que o reclamado lhe dava alimentação; que lhe deu roupas porque rasgou algumas suas; que o reclamado 
tem uma filha; que o reclamado é separado da mulher legítima; que já teve uma outra amante com que tem uma filha; que a filha do reclamado vive com a mãe; que está esperando um filho do reclamado; que tem dezesseis anos completados em 24 de junho de 85 ; que a tratava como sua mulher e não como sua empregada; que procurou esta Justiça por que foi mandada pelo Sr. Albino; que não lhe era pago salário; que assinou o contrato de fls. 03 [contrato de locação de serviços] porque assim quis o reclamado e que o $\mathrm{Sr}$. Albino disse ser este o contrato, parece que lhe foi cobrado C\$ 50.000 para elaboração do referido contrato; que vivia na casa dos pais do reclamante; que as vezes cozinhava para a família toda; que limpava o quarto que era ocupado por ambos; que apanhava na presença dos pais do reclamado; que uma vez a mãe do reclamado disse-o que se tirou a reclamante da casa dos pais não era para o reclamado maltratá-la. Às perguntas do Vogal dos Empregados, respondeu: que o reclamado não tem filhos com a mulher [a esposa]; que não sabe quanto tempo o reclamado conviveu com a mulher; que a família do reclamado tinha uma empregada. Às perguntas dos vogais dos Empregadores, respondeu: que ao assinar o contrato dos autos sabia que o reclamado era casado no civil com outra mulher. Nada mais lhe foi perguntado. Interrogado o reclamado, declarou: que vivia com a reclamante porque gostava dela; que brigavam porque o reclamado saía. Esclarece o depoente que uma vez o depoente chegou as duas da madrugada e a reclamante chegou as oito; que a reclamante estava dormindo na casa da vizinha; que não a espancava que apenas uma vez a empurrou e chegou a lhe dar uns tapas; que toda vez que batia na reclamante a mesma revidava; que a reclamante lavava apenas a roupa de ambos e cuidava do quarto; que não ficou doente no período de três meses; que a reclamante pensou que seria uma coisa e foi outra; que pensou que sairia todas as vezes com o reclamado para dançar, mas o reclamado saía sozinho. (JCJ-ITA/Caixa 01/14, ano 1989, n. de arquivamento 7655)

Chama a atenção a pergunta do "vogal do empregador", ${ }^{17}$ interrogando a trabalhadora quanto a estar ela devidamente esclarecida no momento da assinatura do contrato de locação de serviços domésticos quanto a situação civil matrimonial do patrão. O silêncio daquele operador da justiça à resposta

\footnotetext{
17 Os vogais de "empregados” e de "empregadores”, “juízes classistas”, "leigos”, “não togados", foram previstos no direito brasileiro na década de 1930, eleitos a partir de listas encaminhadas por sindicatos de trabalhadores e de patrões para um mandato temporário, nos moldes da representação paritária do corporativismo de Estado. Com a promulgação da Emenda Constitucional $\mathrm{n}^{\circ}$ 24, de 09 de dezembro de 1999, que extingue as Juntas de Conciliação e Julgamento, substituídas pelas Varas do Trabalho, foi extinta também aquela função.
} 
afirmativa da adolescente soa como conhecida inquisição masculina na sociedade brasileira que parece sempre buscar imputar ao violentado a culpa do algoz. São recorrentes no Brasil os casos de violência sexual em que as mulheres vítimas encontram dificuldades mesmo para o inicial registro de boletins de ocorrência em delegacias policiais, sendo em muitas dessas situações acusadas em lógica perversa da sociedade de classes de terem responsabilidade no crime praticado. A denúncia de espancamento com indicação de testemunha (a mãe do patrão), bem como a condição etária da jovem trabalhadora, sequer são matéria de discussão no processo. A narrativa consolidada pelo escrivão da audiência, finalizada com a pergunta capciosa acima referida do vogal, parece também reforçar dimensões tácitas de desfavoráveis acolhimentos institucionais do pleito da trabalhadora naquela audiência.

As partes "conciliam" em Cr\$ 3.000.000,00, pagos em seis parcelas iguais, valor total superior ao exigido na inicial do processo. Impressiona, ainda, e, sobretudo, a relação de trabalho atravessada pela suposta união matrimonial, de forma que a esposa de fato aparece como doméstica, em um casamento sacramentado por contrato de locação de serviços. Também a Justiça do Trabalho como foro estabelecido para a solução daquele conflito chama a atenção. Nesse aspecto, evidencia-se a capacidade tática (CERTEAU, 1996) de resistência da adolescente e de sua família, apostando no único espaço institucional do estado em que poderiam ser acolhidas, em período e região de difícil reconhecimento de qualquer direito das mulheres, sobretudo do direito ao divórcio. Ainda que a produção desses documentos se dê pelos operadores do direito e da justiça da própria Junta de Conciliação e Julgamento, buscamos ressaltar aqui possibilidades de sua leitura "a contrapelo" (BENJAMIN, 1994: 225), revalorizando a aposta desses sujeitos, mulheres, eventualmente muito jovens, em seu próprio destino, em lugares e situações em que o futuro parece depender sempre dos outros. Efetivamente, a Justiça está em construção, e, assim como a invenção da democracia, não depende dos desígnios e opções da classe dominante, sendo antes aspiração, experiência e saber fazer da classe 
trabalhadora. Também a jurisprudência se constitui pelas ações e experiências de mais sujeitos históricos do que a cabeça-sentença de uma categoria profissional, essa quase sempre de extração social e econômica superior.

Buscando revalorizar a presença de muitos sujeitos nessas lutas, em diálogo ampliado com a sociedade amazonense, queremos ainda enfatizar a importante capacidade de articulação política e cultural de mulheres indígenas na Amazônia brasileira. ${ }^{18}$ No I Encontro de Mulheres do Amazonas, ocorrido no dia 29 de setembro de 1993 na sede da COIAB, na cidade de Manaus, registrou-se em ata o trabalho de troca de experiências a partir de difíceis lembranças. A esperança surge como direito legítimo da memória. Preocupadas em discutir sobre vivências de desigualdades e injustiças sociais, as mulheres indígenas constroem falas de denúncia sobre a falta de saneamento, condições precárias de habitação e acesso à alimentação de má qualidade. São narrativas combativas que denunciam situações de discriminação de gênero e de raça, em falas que aproximam a resistência indígena do movimento negro, e de lutas populares de trabalhadores.

A coordenadora da AMARN abriu o encontro falando sobre os objetivos da AMARN. Em seguida, a Elda Kambeba, A Zenilda deram boas vindas as participantes e na ocasião a Zenilda falou brevemente sobre o objetivo das mulheres se organizarem, o direito das mulheres e como criar alternativas para a autosustentação das mulheres (...) aproveitou para falar sobre a importância das mulheres participarem da campanha da demarcação das terras indígenas. Dando continuidade ao encontro, os participantes se apresentaram individualmente.(...) a representante do PT, Lusarina falou sobre a discriminação sofrida pelas mulheres e dos direitos que possuem (...) licença nos 120 dias durante a maternidade: o direito das empregadas domésticas (...) que precisam educar seus filhos e de lugares, como creches, para poderem trabalhar, além do auxílio saúde. (...) Zelinda Sateré falou que as mulheres são discriminadas porque são índias e que estão começando a se organizarem para conseguirem mudar de vida. Zenilda (...) deu exemplo de uma tia que desde os 13 anos veio para trabalhar na casa de família e que foi expulsa sem direitos da casa dos patrões aos 60 anos. Zeila Sateré acha que uma alternativa para ela e sua família é trabalhar com artesanato para a manutenção dos seus parentes. (...) a

\footnotetext{
${ }^{18}$ Para o aprofundamento da discussão sobre a cultura e resistência de mulheres indígenas e suas experiências também como trabalhadoras domésticas na Amazônia, conf. Miranda (2015).
} 
representante do CIMI falou sobre a resistência indígena, negra e popular. (...) falou da necessidade de se fazer cursos de alimentação alternativa, desenvolver conhecimento sobre medicina natural, e buscar recurso para desenvolver artesanato. Ela se comprometeu para ajudar na realização desses cursos e melhorar o trabalho com o artesanato (Relatório I Encontro de Mulheres do Amazonas, 1993, fls. 1-3. Arquivo Amism).

Zenilda da Silva Vilácio, mencionada no documento, ela própria tendo vivido a experiência de trabalhos domésticos desde a primeira infância, fundou um dos mais expressivos movimentos de mulheres indígenas do estado do Amazonas, a Associação de Mulheres Indígenas Sateré-Mawé (AMISM). Em sua primeira transferência de domicílio para Manaus, Zenilda veio acompanhada de sua avó materna (Mariquinha) para a casa dos tios. A esperança de poder estudar não durou muito, pois logo Zenilda precisou morar com outro casal, na condição de "filha" e "empregada", alcançando então a quarta série da formação escolar. Depois de alguns anos, a mãe de Zenilda pede que retorne à aldeia Ponta Alegre, porém, poucos meses após a sua chegada, o pai, que havia sofrido grave acidente, morre por falta de assistência. Com a perda paterna, Zenilda e suas irmãs migram para Manaus para trabalhar como babás e trabalhadoras domésticas. O processo de mudança é intermediado pela FUNAI.

Aí lá estava como filha, mas aí foi uma equipe da FUNAI lá pra área visitar, né, no tempo do General Coutinho. E lá foi com o tempo, assim, quando estava com uns 6,8 meses, acho, que tinha chegado pra lá, o meu pai morreu de acidente, que ele foi trepar, né, tirar cipó, pra fazer paneiro, aí ele caiu, aí passou uma semana, como não tinha assistência, naquela época, de nada, né. Era mesmo, os patrões exploravam os índios mesmo para trabalhar, eram como escravos. E depois ele morreu. Ficou as 4 irmãs minhas solteiras, a idade de 15 e 16 anos. Aí foi o tempo que a FUNAI foi pra lá e achou que elas eram boas pra ser babás, pra ser empregadas deles, né. Então, achavam que as meninas viessem pra cá elas iam fazer, iam, trabalhar, iam fazer um rancho, isso foi a proposta da equipe da FUNAI, que foi lá, que elas iam trabalhar, aí era de dividir, ia trabalhar, iam fazer o rancho, iam mandar para ela [a mãe] todos os meses. Mas no decorrer do tempo eles não faziam isso, não pagavam, nem uma vez eles pagavam (Entrevista de Zenilda da Silva Vilacio concedida a Wolfgang Kaphammer, 1999. Arquivo Amism). 
Pelo relatório final do Encontro Uma Agenda de Ações Afirmativas para Mulheres Indígenas do Brasil (FUNAI, Brasília, 2002), foro de discussões sobre a criação de políticas sociais públicas do qual participou ativamente Zenilda, somos informados da abrangência institucional e social que envolve o tráfico de meninas para as funções de trabalho doméstico nas cidades da Amazônia. Dona Zenilda, ao considerar a discriminação de companheiras submetidas à experiência de trabalhos servis prestados a "militares e freiras", ressalta a violência praticada contra a mulher indígena.

Militares e freiras: eles levam as mulheres mais novas, mais bonitas e mais fortes para trabalhar lá [na cidade], com as freiras ou em casa de militares, para ser domésticas, servir. Depois, elas ficam por aí... perdidas. E já não conseguem mais nem marido para ficar brincando. (Zenilda da Silva Vilacio - Sateré Mawé apud Relatório do Encontro Ações Afirmativas. Brasília, 2002)

A narrativa acima evidencia grave quadro de exploração de trabalho doméstico infantil, reproduzindo perspectivas que como diz Dona Risoleta, expressam terríveis experiências de violências sofridas por essas mulheres. Também será preciso notar, contudo, que as suas presenças nas páginas deste artigo, pelas circunstâncias em que se deram no momento em que foram registradas, evidenciam capacidade ampliada de resistências, e contribuição importante para a problematização da História do Brasil.

\section{Considerações finais: o humor contra o preconceito de classe}

O lugar das mulheres na historiografia, especificamente o das trabalhadoras domésticas, está em disputa, atomizadas aí muitas vezes na condição de personagens determinadas por um papel a representar na dramaturgia teleológica dos planejadores da vanguarda do futuro. As trabalhadoras que surpreendemos nos documentos que propomos à discussão neste artigo, ao contrário daquelas invisibilizações, reivindicam o direito de entrar "em cena" (SADER, 1988), como sujeitos de sua própria história. A maturidade de suas lutas dialoga com um longo aprendizado da classe 
trabalhadora, o de que a história é "processo" (THOMPSON, 1998). Não é destino, não tem ponto de chegada, não se desloca em trilhos como um "trem" (PEIXOTO, 1990). Sabedoras que são das difíceis correlações de força que enfrentam nessa caminhada aprendem e ensinam a sorrir na construção do seu amanhã. Ao fim e ao cabo, as suas conquistas na sociedade brasileira de ontem e de hoje, ainda fortemente marcada pela cultura escravagista, são avanços da própria democracia. Henfil (1980 e 1984) tematizou em muitas de suas "cartas da mãe" o enorme aprendizado e saber da classe trabalhadora conquistados no enfrentamento com muito diálogo e humor da violência social (contra ela quase sempre implacável). Também nesse meio o cartunista amadureceu o seu riso.

No período que analisamos, evidenciam-se formas de luta que relacionam perspectivas de humor em alinhamento com a causa das trabalhadoras domésticas, explicitando que as disputas pela superação das divisões da sociedade são saturadas de muitos "agoras" (BENJAMIN, 1994: 229). Importante mencionar que, entre as décadas de 1960 e 1980, houve de modo geral na imprensa brasileira crescimento da publicação de histórias em quadrinhos (HQs) ${ }^{19}$, cartuns, charges e desenhos. Citamos as revistas Realidade (1966-1976) e Pasquim (1969-1991) como representantes desse tipo de produção, dentre outras publicações, que contribuíram para a formação crítica e humanista durante a ditadura civil-militar. Nelas a presença de desenhistas como Jaguar, Millôr Fernandes, Fortuna, Ziraldo, Henfil, Angeli, Laerte e muitos outros criaram autonomia estética com personagens e imagens visuais cujos traços, de estilo sensível às dificuldades enfrentadas no cotidiano dos bairros, favelas, fábricas, acesso ao transporte e à educação durante a ditadura, são reveladores das desigualdades sociais, abordando pela via humorística temas polêmicos e urgentes. Nessa chamada imprensa alternativa, que apesar do nome podia alcançar números de venda e tiragem bastante expressivos, representações gráficas de humor revelaram potencial estético emancipatório e crítico sobre a luta de classes. O CPV apoiou a publicação de dois Cadernos de Desenhos Para Uso Popular produzidos pela Arquidiocese de Vitória

\footnotetext{
${ }^{19}$ Sobre o tema, conf. CIRNE (1990).
} 
(1979/1980 e 1981), alcançando esse material extensa distribuição no país, com sua ampla utilização nos materiais de divulgação dos movimentos populares e sindicatos. Naqueles Cadernos de Desenho participaram desde desenhistas conhecidos, como Henfil, Laerte e Nilson, até artistas moradores de comunidades e integrantes de movimentos sociais, além de profissionais convidados e colaboradores da imprensa alternativa.

O historiador Marcos Silva reflete, no livro Rir das ditaduras: os dentes de Henfil (Fradim - 1971/1980), sobre dimensões do cômico na década de 1970 como modo de resistência contra a ditadura no Brasil daquele momento. Observa o autor, tendo em vista um cuidadoso instrumental metodológico no campo da pesquisa em história sobre procedimentos gráficos da produção de cartuns, que "ao invés de considerar a problemática do poder crítico do humor visual como resolvida", é preciso abordar "a rede de conexões culturais e políticas onde tal argumento manifestou eficácia e limites”. (SILVA, 2018: 33).

Henfil foi colaborador do periódico acreano Varadouro - Um jornal das selvas, editado em Rio Branco no período de 1977 a 1981, chegando a manifestar em entrevista para um dos seus fascículos que se emocionara com o fato de que aquela folha não tinha "cheiro de Rio de Janeiro e São Paulo. Tem cheiro de ACRE! A paginação, a leitura, tudo tem cara do Acre!" (ANTONACCI, 1994: 249). O Varadouro foi, ao seu modo, também uma forma de luta dos seringueiros acreanos contra a derrubada da floresta pela frente pecuarista e do agronegócio durante a ditadura civil-militar de 1964 na região. Nesse jornal, "escrito por intelectuais acreanos e de outros estados" (SOUZA, 1998: 222), os seringueiros apareciam falando com voz própria, discutindo nessas páginas as demandas, e apresentando as suas resistências organizadas, ou não, naquele momento. As trabalhadoras domésticas também contribuíram para a produção desses conteúdos. Em reportagem de junho de 1978, na edição comemorativa do primeiro ano do Jornal, a categoria foi representada por depoimentos registrados em matéria com o título "se a gente se unir numa boca só...”, reproduzida aí a fala de uma das trabalhadoras rurais presentes no debate. O encontro foi promovido em razão das comemorações do 
$1^{\text {o }}$ de maio daquele ano, a fim de que pudessem "expor seus problemas e suas reivindicações, levando em conta que, nos últimos anos, suas vozes foram abafadas" (VARADOURO, ano I, n. 10, jun. 1978: 20).

TRABALHADORA DOMÉSTICA: "Nós ouvimos falar aqui sobre salário, salário mínimo. Quem tem e quem não tem. Eu sou das que não tem salário. Tenho 55 anos, 47 de trabalho. Onde? Nas casas de família, trabalho doméstico. E até esta data nunca tive carteira assinada. Eu falava pro meu patrão — "oh, agora chegou o tempo de assinar a carteira" —. Aí a patroa dizia - "tá querendo muita coisa e eu não vou poder dar, não, porque não vou garantir a vida de ninguém, só a minha". Teve patrão que eu trabalhei até 18 anos prá ele. Conhecia a vida dele e ele conhecia a minha também, mas eu acho que o melhor que ele tinha de conhecer ele não conheceu, que era ver que eu estava precisando de uma carteira assinada, que eu precisava, pelo menos, de uma garantia, e não era a vida inteira que eu teria forças prá continuar trabalhando. 47 anos de serviço! E hoje quando peço os meus direitos ao patrão, ele responde - "Ah! vá atrás do Governo porque eu não posso garantir nada prá você, não. Eu ganho prá mim". Vocês vêem aí, 47 anos de trabalho e o que eu ganhei? Qual é o meu salário? Reumatismo! foi o que eu ganhei. Vocês ouçam, minhas irmãs que são empregadas domésticas ou que ainda vão ser: nunca aceitem emprego sem salário, sem carteira assinada, porque os patrões não tem pena, não. Nós precisamos viver melhor porque nós também somos gente, também temos necessidade. Para todas as empregadas domésticas sempre conto a mesma coisa: 47 anos e vejam quanto aborrecimento eu tive, quanto sacrifício enfrentei, quantas vezes, doente, tive que enfrentar o trabalho. Hoje, meu emprego, sabem qual é? Faço doce prá vender, banana frita, e fico adulando todo o mundo prá comprar prá que eu possa viver. É essa a minha situação e é isso que eu vim dizer pra vocês: tenham cuidado, enquanto são novas, são mais mocinhas, peçam, exijam o que é direito de vocês porque senão quando chegarem onde eu cheguei agora, vocês não vão mais ter vida. Só era isso que eu queria dizer. Muito obrigado" (VARADOURO, Ano I, n. 10, jun. 1978:20).

Em matéria de página inteira da edição n. 12 de setembro de 1978 do Varadouro, o tema das experiências e lutas das trabalhadoras domésticas é também discutido. Além das narrativas sobre suas trajetórias próprias de vida, muitas vezes migrantes moradoras das favelas de Rio Branco daquele momento, é também por recurso gráfico humorístico que o tema aparece problematizado. 
No desenho de Henfil, publicado originalmente no Jornal de Brasília (s/d), lemos o diálogo de duas madames sentadas, tomando chá com as pernas cruzadas. Diz a primeira: “- E as domésticas, como vão?” Ao que responde a amiga, dona da casa: “- Mandei as poltronas pra trocar os FORROS...”. Com o termo em negrito e caixa alta, o cartunista evidencia a continuidade de violências que, do pós-abolição, à ditadura que então se enfrentava no país, a escravidão não havia sido superada, quando os "forros", os escravos alforriados, eram agora substituídos pela lógica da escravidão contemporânea: as amigas aparecem sentadas sobre trabalhadoras domésticas, essas em posição "de quatro", expondo o desenho dimensões mórbidas de divertimentos e desejos sexuais relacionados àquela exploração, sugeridos ainda por jogos fisionômicos de prazer, ambiente intimista com abajur, vapores de líquidos quentes e penteados nobres, diferentes dos cabelos contidos e ralos das "serviçais".

Figura 5 Charge de Henfil publicada em Varadouro - Um jornal das selvas/ano II/n. 12/Rio Branco-Acre/setembro de 1978.

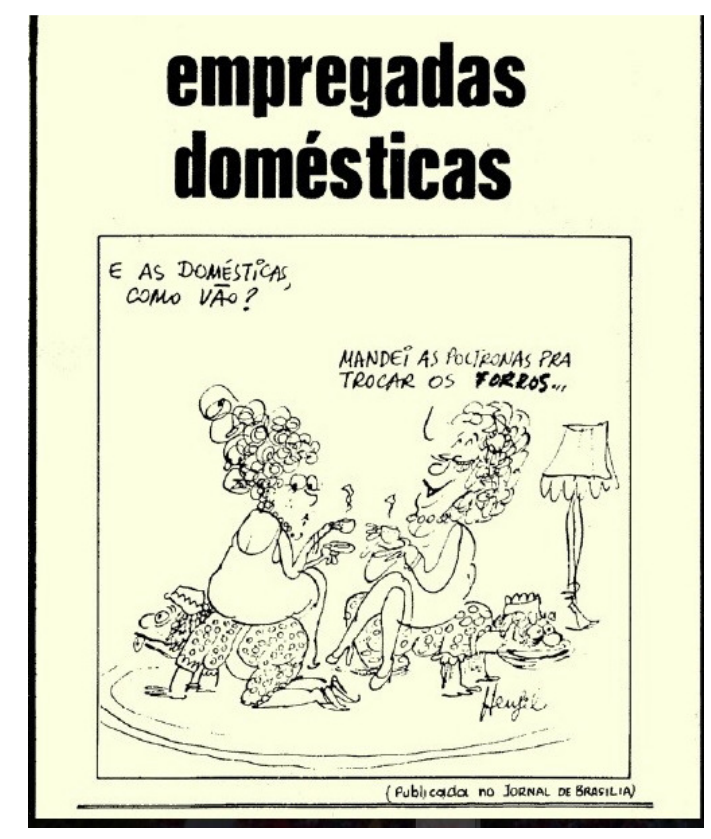

Fonte: Portal da Biblioteca da Floresta/Rio Branco-Acre. 
No desenho de Henfil, publicado originalmente no Jornal de Brasília (s/d), lemos o diálogo de duas madames sentadas, tomando chá com as pernas cruzadas. Diz a primeira: “- E as domésticas, como vão?” Ao que responde a amiga, dona da casa: “- Mandei as poltronas pra trocar os FORROS...”. Com o termo em negrito e caixa alta, o cartunista evidencia a continuidade de violências que, do pós-abolição, à ditadura que então se enfrentava no país, a escravidão não havia sido superada, quando os "forros", os escravos alforriados, eram agora substituídos pela lógica da escravidão contemporânea: as amigas aparecem sentadas sobre trabalhadoras domésticas, essas em posição "de quatro", expondo o desenho dimensões mórbidas de divertimentos e desejos sexuais relacionados àquela exploração, sugeridos ainda por jogos fisionômicos de prazer, ambiente intimista com abajur, vapores de líquidos quentes e penteados nobres, diferentes dos cabelos contidos e ralos das "serviçais". As trabalhadoras manifestam olhar atônito de dor e extenuação física, língua de fora, queixo e sobrancelhas trêmulos. Vale notar que o contraste entre as vestimentas sofisticadas das patroas e os uniformes das “domésticas", esses em tecido estampado de pele de onça (animal silvestre, eventualmente até domesticado, símbolo de valores de dominação e força da elite), reflete dimensões de fetiche da mercadoria inscritas diretamente nos corpos daquelas que são alvo da mais valia do capital privado burguês. Publicado primeiramente em periódico de grande circulação comercial do país, fonte de informação de setores da classe média com acesso privilegiado à imprensa escrita, também na região norte, Henfil sugere com a "madame da esquerda”, que nos fita diretamente, diálogo crítico com práticas de dominação culturalmente disseminadas, também pelo autodenominado campo "progressista" da sociedade. Mais recentemente, o termo "secretária", adotado por esses "empregadores" para designar o trabalho doméstico, tenta amenizar ideologicamente aquelas relações classistas e de injustiça social. A estratégica classista de dissimulação é histórica. O desenho resgata referências de conhecida imagem fotográfica de autor anônimo registrada em fins do século 
XIX em que menina negra serve de "cavalinho" para o divertimento de criança branca da elite.

O trabalho de Henfil nessas páginas dialoga com a face cruel de desigualdades e violências que ainda vivemos no Brasil. Importante enfatizar, contudo, que as fontes aqui analisadas, memórias vivas de um tempo recente, nos permitem afirmar a capacidade de resistência das trabalhadoras domésticas, que impuseram pelo enfrentamento da ditadura de 1964 obstáculos e derrotas a injustiças e interesses de dominação social, saldo positivo de esperanças que movimentam nossas lutas presentes e futuras. Trata-se aí de invenção democrática.

\section{Referências}

ANTONACCI, Maria Antonieta. 'Cultura, trabalho, meio ambiente: estratégias de "empate" no Acre. Revista Brasileira de História, vol. 14, n. 28, pp. 247-67, 1994.

ARQUIDIOCESE DE VITÓRIA. Caderno N. 1 de Desenhos Para Uso Popular. Vitória; São Paulo: Arquidiocese de Vitória/CPV, 1979/1980.

Caderno N. 2 de Desenhos Para Uso Popular. Vitória; São Paulo: Arquidiocese de Vitória/CPV, 1981.

BENJAMIN, Walter. Magia e técnica, arte e política: ensaios sobre literatura e história da cultura. São Paulo: Brasiliense, 1994.

BERNARDINO-COSTA, Joaze. Sindicatos das Trabalhadoras Domésticas no Brasil: Teorias da Descolonização e Saberes Subalternos. Tese de Doutorado em Sociologia. UNB, Brasília/DF, 2007.

BOSI, Ecléa. Memória e Sociedade: lembranças de velhos. São Paulo: Companhia das Letras, 1999.

BLOCH, Marc. Apologia da História, ou, O ofício do historiador. Rio de Janeiro: Zahar, 2001.

BRASIL. Ministério da Justiça. Encontro FUNAI. Uma Agenda de Ações Afirmativas para Mulheres Indígenas do Brasil. Relatório Final. Brasília/DF, 2002. Compilado por Rita Laura Segato.

Presidência da República. Secretaria Especial de Políticas para as

Mulheres. Plano Nacional de Políticas para as Mulheres. Brasília: Secretaria Especial de Políticas para as Mulheres, 2004. Disponível em: https://www.gov.br/mdh/pt-br/navegue-por-temas/politicas-para- 
mulheres/arquivo/assuntos/pnpm/plano-nacional-politicas-mulheres.pdf.

Acesso em: 18 de set. de 2020.

CENTRO DE DOCUMENTAÇÃO E PESQUISA VERGUEIRO (CPV). São Paulo. Série Documental, 1985.

CERTEAU, Michel de. A invenção do cotidiano. Artes de fazer. Petrópolis: Vozes, 1996.

CEVASCO, Maria Elisa. Dez lições sobre estudos culturais. São Paulo: Boitempo, 2008.

CHALHOUB, Sidney. Cidade Febril: cortiços e epidemias na Corte imperial. São Paulo: Companhia das Letras, 1996.

CHAMMAS, Eduardo Zayat. O Correio da Manhã no golpe de 1964: impasses e dilemas na relação com os militares. in: Anais do XXVI Simpósio Nacional de História-ANPUH, São Paulo, julho 2011.

CHAUI, Marilena de S. Apresentando o livro de Lefort. in: LEFORT, Claude. A invenção democrática: os limites do totalitarismo. São Paulo: Brasiliense, 1983.

Conformismo e Resistência: aspectos da cultura popular no Brasil. SP: Brasiliense, 1986.

Cortez, 2003.

Cultura e democracia: o discurso competente e outras falas. SP:

CHAUI, Marilena; CANDIDO, Antonio; ABRAMO, Lelia e MOSTAÇO, Edélcio. Política cultural. Porto Alegre: Mercado Aberto / Fundação Wilson Pinheiro, 1985.

CIRNE, Moacy. História e crítica dos quadrinhos brasileiros. Rio de Janeiro: Europa/Funarte, 1990.

CRESPO, Fernanda Nascimento. O Brasil de Laudelina: usos do biográfico no ensino de história. Dissertação de Mestrado Profissional em Ensino de História. UERJ, Rio de Janeiro, 2016. Disponível em: https://educapes.capes.gov.br/handle/capes/174828. Acesso em: 12 de jan. de 2019.

CRUZ, Heloisa de Faria. Comunicação Popular e Trabalhadores: redes de comunicação e impressos dos movimentos sindicais e populares de São Paulo, 1970/1980. Projeto História, São Paulo, n. 48, dez. 2013.

CRUZ, Heloisa de Faria, PEIXOTO, Maria do Rosário da Cunha. Na oficina do Historiador: conversas sobre História e Imprensa. Projeto História, São Paulo, n. 35, pp. 253-270, dez., 2007. 
FENELON, Déa Ribeiro "O Historiador e a Cultura Popular: história de classe ou história do povo?". História \& Perspectiva, (6), 1992. out. 1995 .

E. P. Thompson - História e Política. Projeto História, São Paulo, (12),

FENELON, Déa Ribeiro; KHOURY, Yara Aun. Ensino e Pesquisa. Fontes para o estudo dos movimentos dos leigos da Igreja Católica no Brasil, 1920-1980. Projeto História, São Paulo, (7), fev. 1987.

FERREIRA, Jorgetânia da Silva. Trabalho em domicílio: quotidiano de trabalhadoras domésticas e donas de casa no Triângulo Mineiro (1950-2005). Tese de Doutoramento em História Social. PUC-SP, São Paulo, 2006.

FREYRE, Gilberto. Casa Grande \& Senzala. Formação da família brasileira sob o regime da economia patriarcal. Rio de Janeiro: Livraria José Olympio Editora, 1933. 1957.

Ordem e Progresso. Rio de Janeiro: Livraria José Olympio Editora,

GRAMSCI, Antonio. Cadernos do Cárcere: Temas de cultura, ação católica, americanismo e fordismo. Rio de Janeiro: Civilização Brasileira, 2015.

HENFIL. Cartas da mãe. Coleção Edições do Pasquim - vol. 92. Rio de Janeiro: CODECRI, 1980.

Diretas Já! Rio de Janeiro: Record, 1984.

INSTITUTO BRASILEIRO DE GEOGRAFIA E ESTATÍSTICA (IBGE). Indicadores IBGE. $O$ trabalho da mulher principal responsável no domicílio (pesquisa mensal de emprego). Governo Federal do Brasil/ Ministério de Estado do Planejamento, Orçamento e Gestão, 2006. Disponível em: https://www.ibge.gov.br/. Acesso em: 03 de mar. de 2019.

JORNAL A força do pobre (CCB Vila Zilda), n. 5, fev., ano II, Coleção Periódicos, Arquivo CPV, São Paulo, 1982. Disponível em: http://www.cpvsp.org.br/periodicos.php. Acesso em: 03 de jan. 2020.

A voz do povo (Lins), n. 4 e 7 (n.8, anotado a caneta), Coleção

Periódicos, Arquivo CPV, São Paulo, 1980. Disponível em: http://www.cpvsp.org.br/periodicos.php. Acesso em: 05 de jan. 2020.

Correio da Manhã. Rio de Janeiro, fascículo de 11 de jan. 1961. Disponível em: http://memoria.bn.br/hdb/periodico.aspx. Acesso em: $12 \mathrm{de} \mathrm{dez.}$ 2019.

Varadouro - Um jornal das selvas, ano I, n. 10 e 12, jun.-set., Rio Branco, Acre, 1978.

KHOURY, Yara Aun (coord.). Inventário do Fundo Juventude Católica (JOC). Acervo do Instituto Nacional de Pastoral - INP/CNBB. São Paulo, CEDIC/COMARTE, 1991. 
KOFES, Suely. Mulher, mulheres: identidade, diferença e desigualdade na relação entre patroas e empregadas domésticas. Campinas: Editora da Unicamp, 2001.

KOSSELECK, Reinhart. Futuro passado - Contribuição à semântica dos tempos históricos. Rio de Janeiro: PUC-RJ/Contraponto, 1979.

LE GOFF, Jacques. História e Memória. Campinas, SP: Editora da Unicamp, 2013.

LEFORT, Claude. A invenção democrática: os limites do totalitarismo. São Paulo: Brasiliense, 1983.

LEVINE, Robert M; MEIHY, José Carlos Sebe Bom. Cinderela Negra: a saga de Carolina Maria de Jesus. Rio de Janeiro: Editora UFRJ, 1994.

MATOS, Maria Izilda S. de. Porta adentro: criados de servir em São Paulo de 1890 a 1930. In:

BRUSCHINI, Cristina e SORJ, Bila (orgs.). Novos olhares: mulheres $e$ relações de gênero no Brasil. São Paulo: Fundação Carlos Chagas, Marco Zero, 1994.

MELO, Maria Luisa de. Primeira vítima do RJ era doméstica e pegou coronavírus da patroa no Leblon, Portal UOL, São Paulo, 19 de março de 2020, Seção Notícias (Saúde). Disponível em: https://noticias.uol.com.br/saude/ultimas-noticias/redacao/2020/03/19/primeiravitima-do-rj-era-domestica-e-pegou-coronavirus-da-patroa.htm. Acesso em: 21 de abr. de 2020.

MIRANDA, Vanessa. Mulheres indígenas na cidade: cultura, saúde e trabalho (Manaus, 1995-2014). Dissertação de Mestrado em Saúde, Sociedade e Endemias na Amazônia. FIOCRUZ/UFAM, Manaus, 2015.

Trabalhadores e trabalhadoras em movimento(s): leigos católicos e outros sujeitos na luta por democracia (ABC Paulista e Grande São Paulo nas décadas de 1970 e 1980). Tese de Doutorado em Psicologia Social. PUC-SP, São Paulo, 2020.

MONTENEGRO, Antonio T. Trabalhadores rurais e justiça do trabalho em tempos de regime civil-militar. in: GOMES, Ângela de Castro e SILVA, Fernando Teixeira da (org.) A Justiça do Trabalho e sua história: os direitos dos trabalhadores no Brasil. Campinas: Editora Unicamp, 2013.

MUNAKATA, Kazumi. "O Lugar do Movimento Operário". História \& Perspectiva (43), pp. 9-40, jul.dez. 2010, Uberlândia: UFU, 2010. 
PAOLI, Maria Celia; Sader, Eder; TELLES, Vera da S. "Pensando a Classe Operária: Os trabalhadores sujeitos ao imaginário acadêmico". Revista Brasileira de História (6), 1983.

PEIXOTO, Maria do Rosário da C. O trem da história: a aliança PCB/CSCB/O PAIZ (Rio de Janeiro, 1923/1924). São Paulo: Marco Zero/CNPq, 1990.

PERROT, Michelle. As mulheres e os silêncios da história. Bauru: EDUSC, 2005.

Os excluídos da história: operários, mulheres e prisioneiros. Rio de Janeiro: Paz e Terra, 2001.

POCHMANN, Marcio. Os pobres novamente sob suspeita. in: Portal RBA Rede Brasil Atual, 25.06.2017. Disponível em: https://www.redebrasilatual.com.br/blogs/blog-na-rede/2017/06/os-pobresnovamente-sob-suspeita. Acesso em: 28 de fev. de 2018.

PORTELLI, Alessandro. Sonhos Ucrônicos. Memórias e possíveis mundos dos trabalhadores. Projeto História, São Paulo, (10), dez., pp. 41-58, 1993.

PRETA-RARA. Eu, Empregada Doméstica. A Senzala moderna é o quartinho da empregada. São Paulo: Letramento, 2019.

RELATÓRIO FINAL. I Encontro de Mulheres do Amazonas. Entrevista de Dona Zenilda da Silva Vilácio concedida a Wolfgang Kapfhammer. Manaus: 29 de set. 1993.

SADER, Eder. Quando novos personagens entraram em cena: experiências e lutas dos trabalhadores da Grande São Paulo, 1970- 1980. Rio de Janeiro: Paz e Terra, 1988.

SAID, Edward W. Cultura e Imperialismo. São Paulo: Companhia das Letras, 2011.

SALLES, Paula Ribeiro. Documentação e Comunicação Popular: a experiência do CPV - Centro Pastoral Vergueiro (São Paulo/SP, 1973-1989). Dissertação de Mestrado em História Social. PUC-SP, São Paulo, 2013.

SAMARA, Eni de Mesquita; SOIHET, Rachel; MATOS, Maria Izilda S. de. Gênero em debate. Trajetórias e perspectivas na historiografia contemporânea. São Paulo: EDUC, 1997

SÃO PAULO (CIDADE); SECRETARIA MUNICIPAL DE CULTURA; DEPARTAMENTO DE PATRIMÔNIO HISTÓRICO. $O$ direito à memoria: Patrimônio histórico e cidadania. São Paulo: DPH, 1992. 
SARLO, Beatriz. Tempo Passado: cultura da memória e guinada subjetiva. São Paulo: Companhia das Letras; Belo Horizonte: UFMG, 2007.

SCOTT, Joan. Gênero: uma categoria útil para análise história. Educação e Realidade, Porto Alegre, 16(2), jul/ dez. 1990, pp. 5-22. Disponível em: https://edisciplinas.usp.br/pluginfile.php/185058/mod_resource/content $/ 2 / \mathrm{G} \% \mathrm{C}$ 3\%AAnero-Joan\%20Scott.pdf. Acesso em: 12 de dez. de 2018.

SILVA, Marcos. Rir das ditaduras: os dentes de Henfil (Fradim - 1971/1980). São Paulo: Intermeios; USP-Programa de Pós-Graduação em História Social, 2018.

SOUZA, Carlos Alberto Alves de. "Varadouros da Liberdade": cultura e trabalho entre os trabalhadores seringueiros do Acre. Projeto História, São Paulo, (16), fev., pp. 221-231, 1998.

SOUZA, Ney de. Trento, o Concílio e seus desdobramentos no Brasil. in: SOUZA, Ney de; GOMES, Edgar da Silva (org.) Trento em movimento. Contexto e Permanências. Jundiaí: Paco Editorial, 2018.

THOMPSON, E. P. A Formação da classe operária inglesa. Rio de Janeiro: Paz e Terra, 1998.

A miséria da teoria ou um planetário de erros: uma crítica ao pensamento de Althusser. Rio de Janeiro: Zahar, 1981.

TOMELIN Jr., Nelson; PEIXOTO, Maria do Rosário da Cunha. Histórias e Justiça em processos trabalhistas: Cultura de resistência de trabalhadores na Amazônia brasileira. Projeto História, São Paulo, n. 58, pp. 298-326, jan.-mar. 2017.

VESENTINI, Carlos Alberto, e DE DECCA, Edgar S.. A revolução do vencedor. Contraponto. São Paulo: I (2): 60/69, nov. 1976.

VIDAL-NAQUET, Pierre. Assassinos da memória: um Eichmann de papel e outros ensaios sobre o revisionismo. Campinas, SP: Papirus, 1988.

WILLIAMS, Raymond. Marxismo e Literatura. Rio de Janeiro: Zahar Editores, 1979.

Recursos da esperança: cultura, democracia, socialismo. São Paulo: Unesp, 2015.

Recebido em: 1 de maio de 2020 Aceito em: 16 de setembro de 2020 